\title{
ASPECTOS JURÍDICOS DO BENEFÍCIO PREVIDENCIÁRIO DA PENSÃO POR MORTE
}

\author{
Priscila Neves Frate ${ }^{1}$ \\ Alberto Antônio Júnior ${ }^{2}$ \\ Mauricio Martins Alves ${ }^{3}$
}

Resumo: Este artigo visa analisar o benefício previdenciário denominado Pensão por Morte, benefício que é devido aos dependentes do segurado, quanto às principais modificações na concessão deste benefício com o advento da Lei $n^{\circ} 13.135$ de 17 de junho de 2015. A partir da doutrina e da jurisprudência consolidada, este artigo defende que a nova diretriz para os dependentes visa um equilíbrio orçamentário, mas gera como consequência um iminente perigo de inserir em situação de risco social os grupos mais vulneráveis. Ao analisarmos a referida lei, mostramos que sua principal finalidade foi eliminar a possibilidade de benefício vitalício, e estabelecer uma programada cessação do referido benefício, gerando, assim, em relação aos beneficiários mais idosos, uma consequência contrária ao objetivo da previdência, colocando em risco a proteção do segurando bem como de seus dependentes.

Palavras-chave: Pensão por morte; Previdência; Seguridade Social.

\footnotetext{
${ }^{1}$ Faculdade de Direito/Universidade do Vale do Paraíba, Brasil. E-mail: priscila_frate@hotmai.com.

2 Faculdade de Direito/Universidade do Vale do Paraíba, Brasil. E-mail: carlos.alberto.antonio.jr@gmail.com.

${ }^{3}$ Faculdade de Direito/Universidade do Vale do Paraíba, Brasil. E-mail: mmalves@univap.br.
} 